\title{
The unattainable trifecta of urban agriculture
}

\author{
Sarita Daftary-Steel a* \\ Food Dignity \\ Hank Herrera ${ }^{b}$ \\ Center for Popular Research, Education, and Policy \\ Christine M. Porter ${ }^{\mathrm{c}}$ \\ Food Dignity and University of Wyoming
}

Submitted June 10, 2015 / Revised August 30 and September 23, 2015 / Accepted September 24, 2015 /

Published online December 20, 2015

Citation: Daftary-Steel, S., Herrera, H., \& Porter, C. M. (2015). The unattainable trifecta of

urban agriculture. Journal of Agriculture, Food Systems, and Community Development, 6(1), 19-32.

http://dx.doi.org/10.5304/jafscd.2015.061.014

Copyright (C) 2015 by New Leaf Associates, Inc.

\section{Abstract}

Urban agriculture (UA) has emerged as a promising way to address many important issues, including growing food for local communities, preserving open space, promoting health, and developing local

a* Corresponding author: Sarita Daftary-Steel, project consultant with Food Dignity, Brooklyn, New York 11207 USA.

Daftary-Steel can be contacted at 345 St. Johns Place; Brooklyn, New York 11238 USA; +1-202-486-0123; daftarysarita@gmail.com

b Hank Herrera, founder and president, Center for Popular Research, Education, and Policy; 840 55th Street, No. 5; Oakland, California 94608 USA.

${ }^{c}$ Christine M. Porter, assistant professor and Wyoming Excellence Chair in Community \& Public Health; and project director and principal investigator, Food Dignity. Division of Kinesiology \& Health, University of Wyoming; 1000 East University Avenue, Department 3196; Laramie, Wyoming 82071 USA; christine.porter@uwyo.edu leaders. A worrying expectation, however, has developed that UA can meet these important and ambitious goals while also being financially sustainable without outside funding. We call this expectation the unattainable trifecta of urban agriculture: the myth that urban agriculture, without long-term funding investments, can

\section{Authors Note}

Sarita Daftary-Steel is the former project director of East New York Farms!, a program of United Community Centers, Brooklyn, New York. Hank Herrera is the former general manager of Dig Deep Farms. Dig Deep Farms is a program of the Alameda County Deputy Sheriffs' Activities League, San Leandro, California.

\section{Acknowledgement}

The Food Dignity project (http://www.fooddignity.org) is funded by Agriculture and Food Research Initiative Competitive Grant no. 2011-68004-30074 from the USDA National Institute of Food and Agriculture. 
simultaneously do three things that are each difficult to do on their own:

(1) Provide good food to people with limited financial resources at prices they can afford.

(2) Provide job training, work experience, and/or leadership development for people typically excluded from employment and/or leadership roles.

(3) Generate income for producers and create jobs funded by profits from sales.

In this reflective essay, we draw from the academic literature on UA and from the combined 30 years of urban agriculture experience of the first two authors to document and discuss both what effects urban agriculture is having and what challenges UA operations face in achieving these social goals. We conclude with recommendations for funders, policy-makers and activists about the broader changes and supports that are needed to make these goals more attainable within the context of UA.

\section{Keywords}

urban agriculture, food access, food systems, employment, job training, sustainability, reflective essay

\section{Introduction}

Urban agriculture (UA) is often ascribed what DeLind (2014, p. 3) calls "phoenix-like effects" for solving urban problems; those effects range from beautifying blighted land, to providing fresh produce to people who otherwise do not have access to it, to revitalizing economies and creating jobs. For example, the titles alone of the following books on UA tout a range of benefits from urban food production: Hunger-proof Cities (Koc, MacRae, Mougeot, \& Welsh, 1999), Growing Cities, Growing Food (Bakker, Dubbeling, Gündel, Sabel Koschella, \& Zeeuw, 2000), Growing Better Cities (Mougeot, 2006), Cities Farming for the Future: Urban Agriculture for Green and Productive Cities (van Veenhuizen, 2006), Women Feeding Cities (Hovorka, de Zeeuw, \& Njenga, 2009) and Urban Agriculture: Food, Jobs, and Sustainable Cities (Smit, Nasr, \& Ratta, 2001). While much of the literature on UA focuses on the Global South, including most of the books in the above list, attention to UA and claims about its benefits have grown rapidly in the United States in the last decade. The U.S. Environmental Protection Agency (EPA), for instance, lists UA benefits as including improving soil, filtering stormwater, improving diets and access to healthy food, improving local skills, increasing property values, promoting physical activity, and teaching "a new generation" (U.S. Environmental Protection Agency, n.d., para. 7). When she was serving as deputy secretary of the U.S. Department of Agriculture, Kathleen Merrigan released a memo suggesting that UA is an "an important tool in confronting several key challenges that Americans face," including supporting farm viability, improving access to healthy and affordable foods, and "realizing the potential of rural-urban linkages" (Merrigan, 2011, para. 2).

What counts as possible benefits of UA depends in part on what activities count as UA. Here, we use the New York City Five Borough Farm project's definition, as it is grounded in the experience of dozens of New York UA operations:

Urban agriculture can be defined as growing fruits, herbs and vegetables, and raising animals in cities, a process that is accompanied by many other complementary activities such as processing and distributing food, collecting and reusing food waste and rainwater, and educating, organizing and employing local residents. (Cohen, Reynolds, \& Sanghvi, 2012, p. 13)

As UA leaders ${ }^{1}$ who have invested decades of our lives in UA-related activities in the United States, we believe in its promise and we have helped some of these promises become reality. However, we have also personally experienced a trend to expect from urban agriculture the potential and responsibility to meet important and ambitious social goals while being financially sustainable without outside funding. Out of the

\footnotetext{
${ }^{1}$ This refers to the first two authors only. The third author supports and learns from UA leaders and organizations.
} 
myriad possible benefits of UA, the UA organizations we have led have been under particular pressure to achieve three goals without long-term external funding:

(1) Provide good food to people with limited financial resources at prices they can afford.

(2) Provide job training, work experience, and/or leadership development for people typically excluded from employment and/or leadership roles.

(3) Generate income for producers and create jobs funded by profits from sales.

We call this list the unattainable trifecta of urban agriculture - the myth that urban agriculture can and should, alone and without long-term funding investments, simultaneously achieve these three goals. As we discuss in this reflective essay, funders, governments, scholars, the media, and activists - including UA practitioners- have collectively set these expectations.

In what follows, we draw not only from the literature but also from our professional experience of decades of UA leadership and on our actionresearch collaborations to contribute to a body of peer-reviewed work that reflects our experience and expertise gained on the ground with UA. To provide context for the three goals of the "unattainable trifecta" posited here, we open by introducing the experience the authors bring to these themes and by cataloging benefits and challenges of UA as described in academic and grey literatures. Then we describe how expectations to meet the trifecta goals have manifested during our UA careers and the challenges we have facing in our work to attain them. Finally, we discuss strategies for activists, funders, and government agencies to help communities attain these three crucial social goals in collaboration with UA initiatives.

\section{Background}

The first two authors have most recently served as UA organizational leaders in East New York Farms! (ENYF) in Brooklyn, New York, and Dig Deep Farms (DDF) in the San Francisco Bay Area.
The work of both UA organizations aligns well with the Five Borough Farm definition of UA, particularly including striving for food access, job creation, and community development goals. The mission of ENYF is "to organize youth and adults to address food justice in our community by promoting local sustainable agriculture and community-led economic development" (East New York Farms!, n.d.). This mission explicitly describes food production as a means of community organizing and fostering economic development. DDF, based in a densely urban yet unincorporated area near Oakland, California, was created as a "social enterprise" project of the Alameda County Deputy Sheriffs' Activities League (Bradley \& Galt, 2014). DDF is "a network of integrated food businesses that provide access to healthy food and jobs in our community where access to both has historically been limited" (Dig Deep Farms, n.d., para. 1). Both of these UA organizations are partners in a collaboration called Food Dignity, which the third author leads. Food Dignity is a five-year action, research, and education project supported with US $\$ 5$ million in funding from the U.S. Department of Agriculture (USDA)'s National Institute of Food and Agriculture's Agriculture Food and Research Initiative (Food Dignity, n.d.).

We have invested significant time and energy in UA through these and other organizations because we believe that UA forms an essential part of a social change strategy for communities to attain the trifecta outlined here. A growing body of UA literature documents many benefits of UA; that literature includes a summary of potential and proven benefits in a framework published by collaborators in the New York City Five Borough Farm Project. Their "metrics framework" outlines health, social, economic, and ecological benefits ascribed to UA, broken down into 19 subcategories of potential benefit. The authors identify at least partial evidence for 9 of those 19 possible benefits, particularly in improving food-health literacy and biodiversity and habitat improvement (Cohen et al., 2012).

In addition, for the subset of UA composed of home and community gardening, a wide body of observational studies report health benefits, such as 
increasing food security (Bushamuka et al., 2005; Stroink \& Nelson, 2009), fruit and vegetable intake (Alaimo, Packnett, Miles, \& Kruger, 2008; Armstrong, 2000; Litt, Soobader, Turbin, Hale, Buchenau, \& Marshall, 2011; Twiss, Dickinson, Duma, Kleinman, Paulsen, \& Rilveria, 2003), and physical activity (Armstrong, 2000; Draper \& Freedman, 2010; Park, Shoemaker, \& Haub, 2009), while reducing stress (Hawkins, Thirlaway, Backx, \& Clayton, 2011; Van Den Berg \& Custers, 2011). Building social capital is another documented community and community health-related benefit of gardening (Alaimo, Reischl, \& Allen, 2010; Firth, Maye, \& Pearson, 2011; Kingsley \& Townsend, 2006).

Recent research also has documented the significant quantities of food produced in UA, in home and community gardens in particular. Garden harvest studies have found yield rates ranging from $0.2 \mathrm{lbs} / \mathrm{ft}^{2}\left(1 \mathrm{~kg} / \mathrm{m}^{2}\right)$ in Paris gardens (Pourias, Duchemin, \& Aubry, 2015) to 0.75 $\mathrm{lbs} / \mathrm{ft}^{2}\left(3.66 \mathrm{~kg} / \mathrm{m}^{2}\right)$ in San Jose, California (Algert, Baameur, \& Renvall, 2014). At the upper end, gardens are more productive per area than the average $0.67 \mathrm{lbs} / \mathrm{ft}^{2}\left(3.27 \mathrm{~kg} / \mathrm{m}^{2}\right)$ yield of vegetable farms (Seufert, Ramankutty, \& Foley, 2012).

Other documented benefits of UA, such as community development, are more limited. Many people we work with directly at DDF, ENYF, and in other similar organizations, however, have consistently reported such benefits. For example, in audio interviews ENYF members discuss, from a personal perspective, reasons that growing food in their community has mattered in their lives, such as feeling connected to neighbors, family, and the earth; improving health; having access to culturally important foods; and feeling agency and pride (East New York Farms!, 2013). New urban farmers at DDF have also described how growing food in and for their community has beautified their environment, improved their individual lives, and improved quality of life as they experience it in their community, sometimes transformatively (see, e.g., Rucker, 2015, and Silva, 2015). Some published case studies have also documented these sorts of community and individual benefits of "complementary activities" in UA (e.g., Atkinson, 2012; Raja, Picard, Baek, \& Delgado, 2014). At the same time, UA, and gardens especially, have been linked to raising property values (Been \& Voicu, 2006) and, therefore property taxes; this could be considered to be contributing to community development, although it could also result in gentrification, which squeezes out the very community hoping to "develop." See also Meenar and Hoover (2012) for a discussion of how UA does and does not further social justice.

Several UA scholars recently debated the benefits of UA, particularly of gardening, in a series of "viewpoint" pieces in this journal. The opening piece argued that the societal benefits of UA are "exaggerated" and noted that the average 43 square foot (4 square meter) garden in Vancouver City is "suitable only for the growing of some flowers, vegetables, and herbs for personal enjoyment" (Hallsworth \& Wong, 2013, p. 12). On the food production front, one rebuttal cited harvest data that the ENYF farm manager had provided (Weissman, 2013), an argument further substantiated by the harvest quantification studies discussed above. ${ }^{2}$ We also agree with respondents' rebuttals to Hallsworth and Wong's singular emphasis on market-scale food production (Colasanti, Hamm, \& 2013; Evans \& Miewald, 2013; Lavid, 2013; Weissman, 2013), without also considering other benefits such as those to health, as indicated in the literature reviewed above, and to families who become not only consumers, but also producers of their own food.

Given that UA often operates on the margins — geographically, financially, and legally (Castillo,

\footnotetext{
${ }^{2}$ If Vancouver City gardens are as productive as those reported in a Camden, New Jersey, study, which yielded 0.51 lb. $/ \mathrm{ft}^{2}$ of produce $\left(2.49 \mathrm{~kg} / \mathrm{m}^{2}\right.$ ) (Vitiello, Nairn, Grisso, \& Swistak, 2010), then the average garden there would yield just under 22 pounds $(10 \mathrm{~kg})$ of food. The USDA recommends that adults eat 2.5 cups a day $\left(5.9 \mathrm{~cm}^{3}\right.$ ) of vegetables (or, for raw leafy greens, 5 cups or $11.8 \mathrm{~cm}^{3}$ ). So, if that yield were all green beans, this would supply an adult with over a month's worth of his or her daily recommended vegetables. If it were all leafy salad greens, the 22 pounds $(10 \mathrm{~kg})$ of yield would represent 2 months of an adult's vegetable supply. (These calculations use measures conducted in Food Dignity, which found that a cup of trimmed, halved and briefly microwaved green beans weighs 3.9 ounces (110.6 g) and 2 cups $\left(4.7 \mathrm{~cm}^{3}\right)$ of raw mixed greens weighs about .95 ounces (26.93 g); each measure was repeated 3 times.)
} 
Winkle, Krauss, Turkewitz, Silva, \& Heinemann, 2013) — the myriad benefits discussed above that it currently yields, even if short of the trifecta of goals we outline, is impressive. Our argument here is that UA requires greater financial and political investments in order to yield the benefits promised by the trifecta of expectations that we outline in the next sections.

\section{Examining the "Trifecta" of UA Expectations}

Expectation 1: Provide good food to people with limited financial resources at prices they can afford.

The Los Angeles Food Policy Council describes UA as "helping to feed everyone, including the unemployed" (Urban Agriculture Working Group, 2014, "Background," para. 3). Of the book titles listed in our introduction, perhaps Hunger-proof Cities most clearly encapsulates the expectation that UA produce nutritionally meaningful quantities of food. Certainly both ENYF and DDF explicitly aim to create access to fresh, healthy, good food for people who would otherwise struggle to afford it. "Good" food being, per the Wallace Center's definition, "not only healthy but also produced in a manner that respects animals and the environment and supports economic viability for all those along the way from farm to table" (Wallace Center, Winrock International, n.d., "Background," para. 1).

But achieving this goal is complicated by at least two significant barriers. One is that for so many people in the U.S., what they can afford to spend on food is so little, particularly people living in neighborhoods such as those that ENYF and DDF call home. The U.S. arguably has a cheap food policy, which enables most people to afford a diet containing sufficient (or even a surfeit of) calories, rather than a living wage policy that would enable working families to afford the real cost of healthy, fresh food (Carolan, 2011). For example, half of households in East New York have incomes of US $\$ 40,000$ or more, while nearly 30 percent earn US $\$ 20,000$ or less, even though the employment rate is 85 percent (Capperis et al., 2013, p. 80). If a family of four receives the maximum annual SNAP benefit of US $\$ 7,788$, this provides an average of US $\$ 7.13$ per family meal
(USDA, 2015). Other food assistance programs, while helpful, provide even less assistance; the Farmers Market Nutrition Program, which provides vouchers for seniors and women with children to use at farmers markets, provides only US $\$ 20$ to US $\$ 24$ per year per household. Therefore, if our UA operations charged the actual cost of producing our locally grown, organic fresh fruits and vegetables, our food would be unaffordable for most people in our neighborhoods. As discussed below, ENYF's produce sale revenues only cover about 2 percent of operational costs for the entire project. This means we either must sell the food we grow at prices below our production costs and make up the difference in other ways, or sell at our real costs, pricing the food out of reach for many people in the communities we exist to serve. ${ }^{3}$

Which brings us to a second problem: our largest food and farm policy programs do not support the production or consumption fresh, healthy food. The striking dissonance between our federal guidelines about what we should eat versus federal supports for what food we produce is noted with each federal farm bill (e.g., Barrington, 2011; Physicians Committee for Responsible Medicine, 2007). The USDA dietary guidelines urge that we fill half of our plates with fruits and vegetables. Yet our federal spending on agriculture programs allocates a fraction of a percent to fruit and vegetable production. Producers of these socalled "specialty crops," then, need to recoup their full cost of production, unlike those growing heavily subsidized commodity crops such as corn and soy. For example, according to the Environmental Working Group farm subsidy database of USDA-provided data, from 1995 to 2012, corn received a total of US\$84.4 billion in subsidies, tobacco producers ${ }^{4}$ received US $\$ 1.5$ billion, and apples garnered US\$262 million (Environmental

\footnotetext{
${ }^{3}$ While helping people to grow their own food, which ENYF does, can ameliorate this problem, there will likely always be large groups of people in any urban area who cannot or do not want to grow their own food.

${ }^{4}$ Since 2004 supports for tobacco farmers have been provided under the "Tobacco Transition Payment Program" (also known as the "tobacco buy-out") to help tobacco producers "transition to the free market" (USDA Farm Service Agency, 2013, para. 1).
} 
Working Group, 2015). While the good food that ENYF and DDF produced did receive some federal support during that time in the form of competitive, short-term grants received, they received zero dollars in annual federal subsidies.

The combined realities of low incomes and comparatively high produce prices mean that the unhealthy options are too often the most affordable and accessible option for millions of people in communities like East New York and the unincorporated areas of Cherryland and Ashland in Alameda County, California, where DDF is located. However, if UA were subsidized at a scale proportional to that provided for commodity agriculture, operations like ENYF and DDF could more feasibly provide fresh, healthy food to people with limited financial resources at prices they can afford while also at least partly achieving the next two UA expectations we discuss below.

Expectation 2: Provide job training, work experience, and/ or leadership development for people typically excluded from employment and/or leadership roles. As the EPA description of UA notes, one of the benefits of our work is teaching "a new generation" about work in general and growing food in particular (n.d., subhead 6). Certainly the need for innovative approaches to job creation and income generation is clear. One in seven young people in the U.S. is "disconnected," meaning not in school and not working (Salemson, 2012). Also, partly related to that, millions of people are released from prisons and jails each year (Re-Entry Policy Council, n.d.), many of whom have a difficult time finding a job. In New York State, the unemployment rate for parolees is 62 percent (New York State Department of Corrections and Community Supervision, 2011). Nearly 4 million Americans suffer from long-term unemployment, defined as such because they have been looking for work and have been unemployed for more than 6 months (Kasperkevic, 2014). These are some of the many Americans who lack a source of stable income, face barriers to employment, and thus are often the target of programs to expand employment opportunities through UA, including at DDF, which has crime prevention and restorative justice missions in addition to the usual UA goals.
Many capable individuals across the country are working hard to create innovative UA projects that can address some of these issues. Because UA is often community-based, therapeutic, and linked to local organizations, combining UA with job training, leadership development, or employment of the "least employable" (such as the differently abled, people with criminal records, or "disconnected" young people) is a natural fit. However, as we have found at ENYF and at DDF, both experienced staff and adequate staff-to-participant ratios are needed to provide appropriate support for people who need job training that goes beyond acquiring technical skills. ENYF provides leadership development and job training for youth ages 13 to 18 through a paid internship program (Daftary-Steel, 2015). DDF provides internship, apprenticeship, and employment opportunities for adults, many of whom have been previously incarcerated. As the story (see sidebar, next page) of one DDF farmer whom we will call Luke illustrates, the challenges many of the employees and interns face each day are not about accessing affordable fruits and vegetables, but about surviving.

Sometimes when we talk about our UA work at conferences, participants ask if we are helping people eat more vegetables. The short answer is almost certainly yes, but also, that is not the most salient point and is not, therefore, how we assess our work. As each of the DDF farmers can attest, consuming more kale does not shield Luke, his coworkers, or their families and friends from the grief puncturing their lives in the form of bullets.

Father Greg Boyle in East Los Angeles says "nothing stops a bullet like a job." The nonprofit he founded partly creates jobs by selling merchandise imprinted with that claim (Homeboy Industries, n.d.). In many communities with entrenched unemployment, people often engage in the informal economy - in particular the illegal drug trade - in order to make a living. Survival in this context is highly skilled, including capacities for keen observation, constant alertness, "reading" people and situations for risk and reward potential, and risk-taking. Often those who have been incarcerated have needed to further hone these skills to survive in jail or prison environments. This context also may operate with an ethic that is vastly 


\section{Luke's Story: A Former Urban Farmer at Dig Deep Farms}

\section{As told by author Hank Herrera}

I call my boss at DDF to check in while waiting for a flight home. He says "Hank, I have bad news. Luke was shot yesterday. But they say he will be OK." Luke was one of our best farmers. I visited him the next day in the hospital. He told me what happened.

They used a four five. They tried to get me, bro'. They tried to knock me down. I kept standing the whole time. But I don't know.... don't know nothin'. I'm just angry, bro'.

Later, at home, I reflected in a note to a friend: "Food justice. Community food security. Tell me what those words mean? We do this work so kids like Luke do not die on the street. So their children do not die on the street. So people do not eat food that poisons them. So kids have real jobs and can someday own real businesses. We believe that we prevent crime with good jobs in our food enterprise. But on a [expletive deleted] street corner in Oakland, nothing stopped those bullets. We all go to work the next day. Soon Luke will return to his job. He loves his job. We love him. Maybe our love, maybe our jobs, maybe our healthy soil, maybe our beautiful vegetables-maybe all of those will someday add up to hope and stop the bullets. Maybe someday the kid who shot Luke will give up his gun for a trowel. Maybe. We all go to work the next day."

In follow-up, we later had to fire Luke when he was found by a deputy sheriff breaking both organizational and legal rules. However, he has survived and even has begun to thrive in a new life he is building for himself.

different than what we call the "work ethic" in the mainstream world; for example, it may depend on demonstrating and enforcing personal loyalty and market dominance with physical violence. Many of these skills, however, are not transferable to the formal economy, in which they are viewed as problem behavior instead of assets and often as cause for dismissal.

Thus UA is creating mainstream work opportunities for people who may have learned very different rules of engagement than they will need for job success, including bringing survival skills that are suddenly reframed as problem behavior. Job "training" in this context requires a highly advanced skill set in addition to those needed for teaching new vocational skills. In our experience, this skill set does not include an unwavering imperative to be "nice." Perhaps "tough love" is the most salient description. These training programs also need to compensate for deficits in math, reading, and writing skills due to poor quality public schools, while also teaching technical skills, including farming, that are may be completely new to participants.

Creating opportunities for the many people chronically excluded from our workforce is a responsibility that our country cannot ignore. But expecting that urban farms could or should do this without long-term investments of outside funds for that purpose is unrealistic, all the more so if we are also expecting people new to farming and even to working in the formal economy to grow enough produce to sell at a profit.

\section{Expectation 3: Generate income for producers} and create jobs funded by profits from sales. The explicit expectation for this often comes from UA organizers and proponents themselves. Van Jones' popular book The Green Collar Economy embodies this hope that "green" jobs in food and energy can, as promised in its subtitle, "fix our two biggest problems" of underemployment and environmental unsustainability (Jones, 2008). This specific potential, outlined in that book, is part of what led the Alameda County Deputy Sheriffs' Activities League to think about founding a UA enterprise in the form of the DDF urban agriculture program. As the DDF mission says, it "provide access to healthy food and jobs" (DDF, n.d.). ENYF's mission explicitly aims in a similar but somewhat different way for "community-led economic development," through our local farmers 
markets where local entrepreneurs (gardeners, cooks, bakers, craftmakers) and regional farmers earn supplemental or primary income. The Los Angeles Food Policy Council UA statement above suggests that "urban agriculture can also contribute to local economic development, and provide much needed jobs" (Urban Agriculture Working Group, 2014, "Background," para. 3). Will Allen, who founded and leads the nation's largest UA operation, Growing Power, notes that "food is the most powerful thing; it is a necessity. It is a way to have fun, and it has the potential to end poverty and to create jobs. When people have jobs and food, it will essentially lower the crime rate. It will enable people to have lifestyles that are sustainable" (Belizaire, 2014, para. 6). As UA activists, we recognize that jobs and income are top priorities for the communities in which we work.

In our experience, funders often implicitly expect this of us, normally in the form of the nearly ubiquitous requirement in requests for proposals to explain how we will sustain our programs and projects in the future, in perpetuity, without any further financial support. For example, a potential funder that visited ENYF praised our strong leadership by community members, our highly successful youth internship program, and our community market, but was disappointed with the percent of revenue generated from produce sales to our community. Their representative suggested that if we did not want to take any of our current land out of community-directed production, perhaps we should start a rooftop farm on the top of our building and start selling this produce at higher prices to restaurants. A rooftop farm focused on high-end products would have involved adding or shifting a significant amount of staff time and required far more capital than we had or the funder would offer. A rooftop location would also move our work literally away from easy community access and view. Since the ENYF produce sells out at our markets each week, selling any of it to restaurants would directly interfere with our goal of meeting the need for fresh produce in our community. We gently explained why these revenuegenerating strategies were not practical for us nor a fit with our mission. We were not invited for a full proposal and they suggested that we reach out to them if we were considering expanding our economic development focus in the future.

Even if our UA organizations did not have multiple social missions, making a farming business even moderately profitable is hard. The median farm operator in the U.S. incurs a net loss (Economic Research Service, 2014). Making a farming business profitable while also trying to provide other social benefits, including making food available at prices people can afford, is even more challenging. This is not because urban gardens or small, sustainable farms are less efficient or less productive than large farms; the opposite appears to be the case (International Assessment of Agricultural Knowledge, Science and Technology for Development [IAASTD], 2008). Within the Food Dignity project, for example, current research with gardeners to quantify their home and community garden harvests in Ithaca, New York, and Laramie, Wyoming, has found that average harvest yields per area in community gardens are on par with yield rates from commercial farms. ${ }^{5}$

Despite high yields per acre, urban farms often face barriers related to scale. Limited space and high property prices mean that urban farms tend to be small in size. Even with high yield rates, total production is constrained by limited land access. This harvest, especially if sold at affordable prices, yields limited revenue. To help improve produce access and expand income-generating opportunities, some UA projects, including ENYF, aggregate produce from a network of urban growers. Although this helps improve access to fresh produce and generates supplemental income to gardeners, it requires heavy investments of staff time and does not usually contribute to the

\footnotetext{
${ }^{5}$ In this study (results not yet published), Cornell University found that harvest yields of 22 experienced gardeners in Ithaca, New York, exceeded half a pound per square foot (2.4 kilograms per square meter), translating to over 14,000 lbs./acre (15,692 kg/hectare). Results from the parallel garden harvest quantification project in Laramie, Wyoming, have been similar, even in the dry, windy and colder climate there. Average per-acre yields in Northeastern U.S. (according to Mohler \& Johnson, 2009) range from 6,000 pounds per acre $(6,725 \mathrm{~kg} /$ hectare) for lighter crops (beans, greens) to 30,000 pounds per acre $(33,626 \mathrm{~kg} /$ hectare $)$ for heavier crops (potatoes, onions).
} 
financial bottom line of the project doing the coordinating.

In sum, though producing and selling food in UA operations does generate some revenue, for those aiming to provide other benefits to their communities, such as affordable food to their neighborhoods and jobs for the least "employable," that revenue will not cover operational costs, much less generate a profit. ENYF, for example, earns about 2 percent of its operating budget through produce sales. City Slicker Farms, a UA organization operating in West Oakland for nearly 15 years, reports covering about 4 percent of its operational costs through sales (City Slicker Farms, 2013). Both of these operations focus exclusively on selling produce within their communities at affordable prices and run related programs that generate no income, such as helping community and backyard gardeners and providing job training and leadership development for teenagers. Growing Power, mentioned earlier as the largest-scale nonprofit UA operation in the U.S., garners about a third of its support from sales and services, but much of this derives from activities other than produce sales, such as conferences and trainings (Lepeska, 2013; GuideStar, n.d.). Thus for most UA operations working for multiple community goals, although produce sales provide an important pool of unrestricted funds, the challenges to achieving profitability mean that support for income generation and jobs cannot be derived from produce sales alone.

\section{Discussion}

All of the goals embodied in the trifecta we describe above represent necessary, if not sufficient, elements for building socially, economically and ecologically sustainable, healthy, and foodsecure communities. UA projects and programs are well placed to contribute substantially to all three goals, including by activating often overlooked or underused assets such as vacant lots, rooftop space, and human potential and expertise. Additionally, UA projects that fulfill their greatest potential offer all kinds of underfunded "public goods," including healthy food, physical activity, education, public space, socially integrated aging, mental health, job readiness, and environmental stewardship, to name a few (Cohen, Reynolds, \& Sanghvi, 2012). We can only do, sustain, and expand our work, however, with external investments or major shifts in our national wage structure.

Most UA organization operators know that we cannot meet the expectations to sell healthy food at prices that poor people can afford (i.e., have lower sales income) and provide substantial traditional and nontraditional workforce training (i.e., have higher production costs), while also generating sufficient income from sales to sustain a business. But in our experience, many UA operations are reluctant to admit this, at least publicly. Such an admission can look like a failure of their organization or enterprise, rather than a realistic statement about the failures of broader systems and what kind of support is required to enable UA operations to address some of these failures (Lawson, 2005). Some practitioners are speaking up and trying to craft a better-informed narrative of what makes an UA project successful (Johnson, 2014). Urban agriculture, in the words of LaDonna Redmond, requires "becoming organizers and not food science providers" (DeLind, 2014, p. 5).

So, although UA projects all over the country offer creative and effective responses to food access, land use, education, employment, and environmental issues, when we expect UA to tackle all of these issues without substantial outside support, we are encouraging UA organizations to pursue unattainable goals, and to fail—sometimes very publicly and sometimes by silently failing at some part of their mission. Some organizations know that meeting this triplet of goals is not realistic, but in response to the pressure they feel from funders or the media, they may tell a story that makes it seem possible, and that becomes the expectation to which others are held.

For example, as in the earlier story about a potential funder visit, ENYF staff are asked fairly often if we could sell some of our produce to highend buyers to subsidize the cost of other produce that we sell to our community at low prices. The realistic answer is, not really. The United Community Centers Youth Farm, a half-acre ( 0.20 hectare) farm powered by youth interns that forms one component of ENYF, sells about US\$10,000 
worth of produce each year. If we took a quarter of that produce, quadrupled the price, and sold it to upscale restaurants, we would make an extra US $\$ 7,500$, toward a total annual budget of US $\$ 430,000 .{ }^{6}$ For that US $\$ 7,500$, we would have to shift our mission, start a new program area focusing staff time on securing and delivering to highend customers, and make our farm stand in our own community, which quickly sells out of most items, 25 percent emptier.

In our experience, many UA operations strive to be self-financing because they realize the challenges of being reliant on outside funding, especially foundation grants, which tend to be small, are rarely multiyear, are highly competitive, and require substantial quantities of staff time to acquire and manage. Below we outline our suggestions for making UA operations more sustainable while still enabling them to fill a need for affordable fresh food and transformative work and leadership training for our communities.

\section{Implications for UA Operations}

Make choices. Decide which one or two of these three things you can do, and do those well. For example, you can be a for-profit farm demonstrating the economic potential of sustainable urban agriculture, or a project using urban agriculture to provide food access and job training or leadership development for marginalized communities, but probably not all three.

Be honest with yourself, your funders, the media, and your community. If we say we can do everything, people will expect us to. If you thought you could do all of this, and realized that in reality you're doing only one or two of these things well, share that story.

\footnotetext{
${ }^{6}$ Even though ENYF programs are so integrated that it's hard to truly separate costs, we estimate that the UCC Youth Farm costs alone are about US $\$ 38,000$ per year. This does not include any youth program labor, but does include farm manager labor, and time spent leading educational tours and hosting volunteers, since we cannot imagine running our farm and refusing to let a local first-grade class visit, for example. Staff salaries are low for New York City (US $\$ 35,000$ US $\$ 40,000$ per year), and overhead is low because we pay no rent for our basement office space.
}

Advocate for a new public agenda for $U A$, particularly renaming and expanding support for "specialty crops" and supporting some UA activities with social services funding streams, as described below.

Link your work with other groups working for related goals in our communities, such as living wage laws, education equality, and criminal justice reform. Creating healthy food systems has inextricable links to a healthy economic system, a healthy system of health care, a healthy criminal justice system, and a healthy environment.

\section{Implications for UA Funders and Policy- makers}

Learn the reality of what it will take for urban farms to do effective leadership development or job training work, and allow the time and money to support that, including and especially for staff time.

Welcome the expertise and experience of practitioners. This includes, especially on the part of funders, asking real questions (with no "right" answers) about how a UA operation is working and welcoming honest answers to better support this work.

Keep supporting $U A$ for all of the physical, social, environmental, and educational benefits it generates in communities. Many UA operations with broad social goals struggle to garner enough grant support to do their work well. Without other external supports like low or no rent for land and office space, DDF and ENYF probably would not be able to achieve even two out of the trifecta's three goals. SNAP incentive programs and other federal food assistance programs also help to keep the multiple goals of UA in operation.

Support "specialty crops" in the farm bill at a scale more proportionate to the U.S. Dietary Guidelines (and start calling them fruits and vegetables). In federal agricultural policy, the foods that are supposed to fill half our plate are called "specialty crops." This phrasing is indicative of the miniscule financial supports for growing fruits and vegetables vs. commodity crops such as corn, cotton, wheat, and soy. More of our tax dollars should support fruit and vegetable 
production and, just as importantly, in ways that make those supports proportionately available to smaller producers, including urban farms. Also, while this is not a UA-specific issue, citizen and congressional support for such a measure might be easier to muster if we called them what they are, fruits and vegetables, in the farm bill legislation.

Commit some parts of funding streams for "standard" publicly funded social services to $U A$ programs working to tackle root causes of deep social problems that give rise to the need for such services. This could offer a way for social work, employment, nutrition, and criminal justice services to begin to solve, rather than simply manage, these issues. The city of New York's Green Thumb program, run as a function of the parks and recreation department and funded by a HUD Community Development Block Grant, is a small-scale example of this type of funding that is helping community gardening operations. In California, DDF represents a groundbreaking attempt at this strategy in collaboration with many Alameda County government partners, and one that earned the state of California's Counties Innovation Award in 2014 (Alameda County Board of Supervisors, 2014). The growing cadre of federal USDA programs that support UA, such as the Farmers' Market Nutrition Program, are also small but important steps in this direction.

\section{Conclusion}

With the strategies, supports, and structures we outline above, UA operations could eventually achieve the first two goals of the trifecta: providing access to fresh food at affordable prices and operating sustainably with enough income to pay a living wage to their work force. To enable the educational aims of urban agriculture-specifically, the intensive job training and leadership development for marginalized people outlined here-UA operators, especially those trying to make their produce accessible to low- and middle-income people, will likely still need external financial support, in the same way that our public education institutions need external financial support.

In this essay, we have outlined three ambitious goals that speak to the potential of urban agriculture and to the issues we need to address in order for all people to live healthy, stable, dignified lives. We argue that UA is valuable even when it is not profitable, and that our colleagues, funders, policymakers, supporters, and critics should consider ways, as described above, to both support UA and to address root causes of the social issues that have driven UA initiatives to sprout in vacant lots all over the country.

\section{References}

Alaimo, K., Packnett, E., Miles, R. A., \& Kruger, D. J. (2008). Fruit and vegetable intake among urban community gardeners. Journal of Nutrition Education and Behavior, 40(2), 94-101. http://dx.doi.org/10.1016/j.jneb.2006.12.003

Alaimo, K., Reischl, T. M., \& Allen, J. O. (2010). Community gardening, neighborhood meetings, and social capital. Journal of Community Psychology, 38(4), 497-514. http://dx.doi.org/10.1002/jcop.20378

Alameda County Board of Supervisors. (2014, September 11). Alameda County a big winner in statewide awards competition [Press release]. Retrieved from http://www.acgov.org/news/ pressreleases/pr2014-09-12CSACawards.pdf

Algert, S. J., Baameur, A., \& Renvall, M. J. (2014). Vegetable output and cost savings of community gardens in San Jose, California. Journal of the Academy of Nutrition and Dietetics, 114(7), 1072-1076. http://dx.doi.org/10.1016/j.jand.2014.02.030

Armstrong, D. (2000). A survey of community gardens in upstate New York: Implications for health promotion and community development. Health \& Place, 6(4), 319-327. http://dx.doi.org/10.1016/S1353-8292(00)00013-7

Atkinson, A. E. (2012). Promoting health and development in Detroit through gardens and urban agriculture. Health Affairs, 31(12), 2787-2788. http://dx.doi.org/10.1377/hlthaff.2012.1106

Bakker, N., Dubbeling, M., Gündel, S., Sabel-Koschella, U., \& de Zeeuw, H. (Eds.). (2000). Growing cities, growing food: Urban agriculture on the policy agenda. A reader on urban agriculture. Feldafing, Germany: Deutsche Stiftung für internationale Entwicklung.

Barrington, V. (2011, November 17). Wake up to the (secret) Farm Bill. Ecosalon. Retrieved from http://ecosalon.com/the-secret-farm-bill-foodpolicy-402/ 
Been, V., \& Voicu, I. (2006). The effect of community gardens on neighboring property values (New York University Law and Economics Working Papers No. 46). New York: New York University. Retreived from http://1sr.nellco.org/nyu lewp/46

Belizaire, G. (2014, July 30). Will Allen’s ‘Growing Power' is using urban farming to change the existing food system in the U.S. and beyond. emPower Magazine. Retrieved from http://www.empowermagazine.com/will-allensgrowing-power-using-urban-farming-changeexisting-food-system-u-s-beyond/

Bradley, K., \& Galt, R. E. (2014). Practicing food justice at Dig Deep Farms \& Produce, East Bay Area, California: Self-determination as a guiding value and intersections with foodie logics. Local Environment, 19(2), 172-186. http://dx.doi.org/10.1080/13549839.2013.790350

Bushamuka, V. N., de Pee, S., Talukder, A., Kiess, L., Panagides, D., Taher, A., \& Bloem, M. (2005). Impact of a homestead gardening program on household food security and empowerment of women in Bangladesh. Food Nutrition Bulletin, 26(1), 17-25. Retrieved from http://www.ncbi.nlm.nih.gov/pubmed/15810795

Capperis, S., De la Roca, J., Findlan, K., Ellen, E. G., Madar, J., Moriarty, S.,...Willis, M. (2013). State of New York City's housing and neighborhoods in 2013. New York: NYU Furman Center. http://furmancenter.org/files/sotc/SOC2013 HighRes.pdf

Carolan, M. (2011). The real cost of cheap food. Abingdon, UK: Earthscan.

Castillo, S. R., Winkle, C. R., Krauss, S., Turkewitz, A., Silva, C., \& Heinemann, E. S. (2013). Regulatory and other barriers to urban and peri-urban agriculture: A case study of urban planners and urban farmers from the greater Chicago metropolitan area. Journal of Agriculture, Food Systems, and Community Development, 3(3), 155-166. http://dx.doi.org/10.5304/jafscd.2013.033.001

City Slicker Farms. (2013). City Slicker Farms' 2013 annual report. Oakland, California: City Slicker Farms.

Cohen, N., Reynolds, K., \& Sanghvi, R. (2012). Five Borough Farm: Seeding the future of urban agriculture in New York City. New York: Design Trust for Public Space in partnership with Added Value.

Colasanti, K., \& Hamm, M. (2013). Increased productivity, role in alleviating food insecurity possible. Journal of Agriculture, Food Systems, and Community Development, 3(2), 15-16. http://dx.doi.org/10.5304/jafscd.2013.032.011

Daftary-Steel, S. (2015). Growing young leaders in East New York: Lessons from the East New York Farms! Youth Internship Program. Brooklyn, New York: East New York Farms! Retrieved from http:/ / fooddignity. org/wp/wp-content/uploads/2015/04/ENYF-1504-28-report-Growing-Young-Leaders.pdf

DeLind, L. B. (2014). Where have all the houses (among other things) gone? Some critical reflections on urban agriculture. Renewable Agriculture and Food Systems, 30(1), 3-7. http://dx.doi.org/10.1017/S1742170513000525

Dig Deep Farms. (n.d.). About us. Retrieved August 22, 2015, from http://digdeepfarms.com/about-us/

Draper, C., \& Freedman, D. (2010). Review and analysis of the benefits, purposes, and motivations associated with community gardening in the United States. Journal of Community Practice, 18(4), 458-492. http://dx.doi.org/10.1080/10705422.2010.519682

East New York Farms! (n.d.). East New York Farms! Retrieved August 22, 2015, from http://www.eastnewyorkfarms.org

East New York Farms! (2013). Profiles. Retrieved August 22, 2015, from http://www.eastnewyorkfarms. org/index.php?option $=$ com_content $\& v$ view $=$ article \&id $=73$ \&Itemid $=26$

Environmental Working Group. (2015). EWG farm subsidies database. Retrieved August 22, 2015, from http: / / farm.ewg.org/region.php?fips $=00000 \& p r o g$ code $=$ total

Evans, T. L., \& Miewald, C. (2013). Cultivating more than food: Where community gardens fit with what cities do. Journal of Agriculture, Food Systems, and Community Development, 3(2), 19-21. http://dx.doi.org/10.5304/jafscd.2013.032.013

Firth, C., Maye, D., \& Pearson, D. (2011). Developing "community" in community gardens. Local Environment, 16(6), 555-568. http://dx.doi.org/10.1080/13549839.2011.586025

Food Dignity. (n.d.) Welcome. Retrieved August 22, 2015, from http://www.fooddignity.org

GuideStar. (n.d.). Growing Power Inc.: Forms 990 from the IRS. Retrieved from http://www.guidestar.org/ PartnerReport.aspx?Partner=foundationsource\&ein =39-1876495 
Hallsworth, A., \& Wong, A. (2013). Urban gardening: A valuable activity, but... Journal of Agriculture, Food Systems, and Community Development, 3(2), 11-14. http://dx.doi.org/10.5304/jafscd.2013.032.010

Hawkins, J. L., Thirlaway, K. J., Backx, K., \& Clayton, D. A. (2011). Allotment gardening and other leisure activities for stress reduction and healthy aging. HortTechnology, 21(5), 577-585.

Homeboy Industries. (n.d.). Homeboy and Homegirl merchandise. Retrieved August 22, 2015, from http://www.homeboyindustries.org/shophomeboy/

Hovorka, A., de Zeeuw, H., \& Njenga, M. (2009). Women feeding cities: Mainstreaming gender in urban agriculture and food security. Rugby, UK: Practical Action Publishing. http://dx.doi.org/10.3362/9781780440460

International Assessment of Agricultural Knowledge, Science and Technology for Development [IAASTD]. (2008). Agriculture at a crossroads. Johannesburg, South Africa: Author.

Johnson, N. (2014) Urban farms won't feed us, but they just might teach us. Retrieved from http:/ / grist.org/ food/urban-farms-wont-feed-us-but-they-justmight-teach-us/

Jones, V. (2008). The green collar economy: How one solution can fix our two biggest problems. New York: HarperOne.

Kasperkevic, J. (2014, March 27). The ghosts of America's long-term unemployed. The Guardian. Retrieved from http://www.theguardian.com/ money/us-money-blog/2014/mar/27/us-longterm-unemployed-ghosts-economy-jobs

Kingsley, J. Y., \& 'Townsend, M. (2006). 'Dig in' to social capital: Community gardens as mechanisms for growing urban social connectedness. Urban Policy and Research, 24(4), 525-537. http://dx.doi.org/10.1080/08111140601035200

Koc, M., MacRae, R., Mougeot, L. J. A., \& Welsh, J. (Eds.). (1999). For hunger-proof cities: Sustainable urban food systems. Ottawa, Canada: International Development Research Centre.

Lavid, L. (2013). Urban gardens: Part of a whole system approach. Journal of Agriculture, Food Systems, and Community Development, 3(2), 17-18. http://dx.doi.org/10.5304/jafscd.2013.032.012

Lawson, L. (2005). City bountiful: A century of community gardening in America. Berkeley, California: University of California Press.

Lepeska, D. (2013, January 14). Betting the farm: Is there an urban agriculture bubble? Forefront, 2(40).

Retrieved from http://nextcity.org/features/view/ betting-the-farm

Litt, J. S., Soobader, M.-J., Turbin, M. S., Hale, J. W., Buchenau, M., \& Marshall, J. A. (2011). The influence of social involvement, neighborhood aesthetics, and community garden participation on fruit and vegetable consumption. American Journal of Public Health, 101(8), 1466-1473. http://dx.doi.org/10.2105/AJPH.2010.300111

Meenar, M. R., \& Hoover, B.M. (2012). Community food security via urban agriculture: Understanding people, place, economy, and accessibility from a food justice perspective. Journal of Agriculture, Food Systems, and Community Development, 3(1), 143-160. http://dx.doi.org/10.5304/jafscd.2012.031.013

Merrigan, K. A. (2011, October 14). Urban agriculture and gardening - Supporting farm viability, building access to nutritious, affordable food and encouraging rural-urban linkages [USDA press release]. Retrieved from http://www.usda.gov/ documents/usda-urban-ag-memo-final.pdf

Mohler, C. L., \& Johnson, S. E. (Eds.). (2009). Crop rotation on organic farms: A planning manual (NRAES177). Ithaca, New York: Natural Resource, Agriculture, and Engineering Service. Retrieved from http://www.nraes.org

Mougeot, L. J. A. (2006). Growing better cities: Urban agriculture for sustainable development. Ottawa, Canada: International Development Research Centre.

New York State Department of Corrections and Community Supervision. (2011). Parolee facts. Retrieved August 22, 2015, from http://www.parole.ny.gov/program stats.html

Park, S.-A., Shoemaker, C. A., \& Haub, M. D. (2009). Physical and psychological health conditions of older adults classified as gardeners or nongardeners. HortScience, 44(1), 206-210.

Physicians Committee for Responsible Medicine. (2007). Health vs. pork: Congress debates the Farm Bill.

Retrieved December 17, 2015, from https://web.archive.org/web/20110902140706/htt p://www.pcrm.org/good-medicine/2007/autumn/ health-vs-pork-congress-debates-the-farm-bill

Pourias, J., Duchemin, E., \& Aubry, C. (2015). Products from urban collective gardens: Food for thought or for consumption? Insights from Paris and Montreal. Journal of Agriculture, Food Systems, and Community Development, 5(2), 175-199. http://dx.doi.org/10.5304/jafscd.2015.052.005 
Raja, S., Picard, D., Baek, S., \& Delgado, C. (2014). Rustbelt radicalism: A decade of food systems planning in Buffalo, New York (USA). Journal of Agriculture, Food Systems, and Community Development, 4(4), 173-189. http://dx.doi.org/10.5304/jafscd.2014.044.015

Re-Entry Policy Council. (n.d.). Report of the Re-Entry Policy Council: Charting the safe and successful return of prisoners to the community. Retrived from http://www.csgjusticecenter.org/wpcontent/uploads/2013/04/1694-11.pdf

Rucker, P. (2015, July 8). "Fresh Start," a digital story from Paths to Food Dignity [Video file]. Retrieved from https://www.youtube.com/watch? $\mathrm{v}=$ fjnIjAvLUJo\&list=PL2zMrq22-Y2tanDzKh B6L945wpkkgQEEe\&index $=2$

Salemson, D. (2012, November 15). 5.8 million disconnected youth nationally; 350k in NYC [Blog post]. Jobs First NYC. Retrieved from http://blog.jobsfirstnyc.org/2012/11/58-milliondisconnected-youth.html

Seufert, V., Ramankutty, N., \& Foley, J. A. (2012). Comparing the yields of organic and conventional agriculture. Nature, 485(7397), 229-232. http://dx.doi.org/10.1038/nature11069

Silva, M. (2015, July 8). "My New Life," a digital story from Paths to Food Dignity [Video file]. Retrieved from https://www.youtube.com/watch? $\mathrm{v}=$ yI3wjw1Nn84\&index=1\&list=PL2zMrq22Y2tanDzKhB6L945wpkkgQEEe

Smit, J., Nasr, J., \& Ratta, A. (2001). Urban agriculture: Food, jobs and sustainable cities_2001 edition. New York: Urban Agriculture Network.

Stroink, M. L., \& Nelson, C. H. (2009). Aboriginal health learning in the forest and cultivated gardens: Building a nutritious and sustainable food system. Journal of Agromedicine, 14(2), 263-269. http://dx.doi.org/10.1080/10599240902739737

Twiss, J., Dickinson, J., Duma, S., Kleinman, T., Paulsen, H., \& Rilveria, L. (2003). Community gardens: Lessons learned from California healthy cities and communities. American Journal of Public Health, 93(9), 1435-1438. http://dx.doi.org/10.2105/AJPH.93.9.1435

U.S. Department of Agriculture [USDA]. (2015).
Supplemental Nutrition Assistance Program (SNAP): How much could I receive? Retrieved August 22, 2015, from http://www.fns.usda.gov/ snap/how-much-could-i-receive

USDA Economic Research Service. (2014). Farm household income (Historical). Retrieved August 22, 2015, from http://www.ers.usda.gov/topics/ farm-economy/farm-household-well-being/farmhousehold-income-\%28historical\%29.aspx\#. VD2hjxZhG5I

USDA Farm Service Agency. (2013). Tobacco Transition Payment Program. Retrieved August 22, 2015, from http://www.fsa.usda.gov/FSA/ webapp?area $=$ home\&subject $=$ toba\&topic $=$ landing

U.S. Environmental Protection Agency [EPA]. (n.d.). Brownfields: Urban Agriculture: Basic Information. Retrieved August 22, 2015, from https://web.archive.org/web/20150618191746/htt p://www.epa.gov/brownfields/urbanag/basic.htm

Urban Agriculture Working Group. (2014). Urban agriculture. Retrieved August 22, 2015, from http://goodfoodla.org/policymaking/workinggroups-2/urban-agriculture/

Van Den Berg, A. E., \& Custers, M. H. G. (2011). Gardening promotes neuroendocrine and affective restoration from stress. Journal of Health Psychology, 16(1), 3-11. http://dx.doi.org/10.1177/1359105310365577

van Veenhuizen, R. (Ed.). (2006). Cities farming for the future: Urban agriculture for green and productive cities. Silang, Philippines: International Institute of Rural Reconstruction and ETC Urban Agriculture.

Vitiello, D., Nairn, M., Grisso, J. A., \& Swistak, N. (2010). Community gardening in Camden, NJ: Harvest report: Summer 2009. Philadelphia, Pennsylvania: University of Pennsylvania. Retrieved from http:/ / camdenchildrensgarden.org/ Community Gardening Harvest Report.pdf

Wallace Center, Winrock International. (n.d.). National Good Food Network. Retrieved August 22, 2015, from http://www.wallacecenter.org/ngfn/

Weissman, E. (2013). No buts about it...The value of urban food production. Journal of Agriculture, Food Systems, and Community Development, 3(2), 23-24. http://dx.doi.org/10.5304/jafscd.2013.032.014 